\title{
The Context Specific Factors Affecting Women Empowerment and Empowerment's Implications for Resource Allocation, Awareness and Fertility: an Econometric Analysis
}

\author{
Mohammad Mokammel Karim Toufique ${ }^{1, a^{*}}$ \\ ${ }^{1}$ Assistant Professor, Department of Economics \\ United International University \\ UIU Bhaban, House \# 80, Road \# 8/A (Old-15) \\ Satmasjid Road, Dhanmondi \\ Dhaka-1209, Bangladesh \\ aEmail: mktoufique@gmail.com
}

\begin{abstract}
Keywords: Women Empowerment, Determinants of Empowerment, Impacts of Empowerment, Resource Allocation, Awareness, Family Planning.
\end{abstract}

\begin{abstract}
Using data from a survey of Bangladeshi households, this paper constructs an index of women empowerment and explores both the determinants of empowerment of married women and the impacts that empowerment has on various aspects of a woman's life. The findings reveal that female education, her involvement in income generating activities (both formal and informal) and the structure of the household (unit or extended) are important determinants. As regards the impacts of empowerment on the female's life, the paper finds that empowerment affects her food intake and expenditure patterns in quantitative and qualitative terms - it positively impacts women's nutritional status and health care and confers positive impacts on taking family planning measures. Also empowered women's behavior is less discriminating when it comes to serving food among family members.
\end{abstract}

\section{INTRODUCTION}

A basic problem when dealing with female empowerment is that measuring empowerment has always been a difficult task and there is hardly any consensus. Also a single empowerment indicator is certainly not appropriate for every economy since empowerment is influenced by various socio-econ-cultural factors that are not unique to every community. Hence the measurement of female empowerment is highly context-specific. So it might be interesting to investigate the factors determining women's empowerment in Bangladesh and the potential impacts that empowerment has on a woman's life.

Empowerment is a process that enables disempowered individuals or groups to acquire power to 'control their lives and the ability to make strategic life choices' [1]. A number of studies have portrayed the fact that better access to outside-home employment raises a woman's in-house decision-making ability as well as control over economic resources. Again many have argued that the ownership of assets may largely enhance the autonomy of females whether some have presented a link between pre-marital assets and female autonomy. Some studies have shown the importance of mothers' status for their children's nutritional status in countries like Rwanda, Jamaica, Thailand, Jordan and Malawi $[2,3,4,5,6]$. There is evidence that if women's share of household income rises, budget share of food rises. Also, its impact on meals eaten out, clothing and expenditure on alcohol and cigarette are found to be negative [7]. For Guatemala, a paper reveals a significant positive relationship between the mother's share of family earnings and children's health status [8]. Utilizing data from Bangladesh, Ethiopia, Indonesia, and South Africa, another paper finds the relative bargaining power of women having significantly different impacts on different types of expenditure [9].

The influence of home-based production, religion and region was studied by some researchers $[10,11]$. One research examined the link between education and various aspects of women empowerment and found no positive linear relationship between education and the economic, social 
and political empowerment of females [12]. Also a number of factors were brought up to yardstick women's empowerment such as: domestic decision-making; finance and resource allocation; social and domestic matters; child related issues; access to or control over resources; freedom of movement; and so on [13].

In Bangladesh a study identified six dimensions of empowerment: 1. Sense of Self and Vision of the Future; 2. Mobility and Visibility; 3. Economic Security; 4. Decision Making Power in the Household; 5. Participation in Non-Family Groups; 6. Interact Effectively in the Public Sphere [14]. Some likely indicators of female empowerment are: family structure, marital characteristics, financial autonomy, freedom of movement, and lifetime experience of employment participation in the modern sector [15]. Using data from Bangladesh, another study examined the determinants of women's within-household autonomy particularly focusing on the relative contribution of earned versus unearned income in raising female autonomy and the role of employment outside the husband's farm [16].

Apart from analyzing the determinants of female empowerment, this paper examines a couple of issues - i) if the relatively empowered women are taking more calories ii) as it is often argued that total calorie intake focuses only on the quantity aspect of food sufficiency and ignores 'quality' of the diet [17], this paper also examines the relationship between women's empowerment and the quality of her diet iii) links between female empowerment and food as well as various non food expenditures are investigated iv) other potential impacts of empowerment are explored.

\section{DATA AND METHODOLOGY}

The paper takes advantage of a unique survey of Bangladeshi households, with a special emphasis on intra-household issues, which was conducted by the Bureau of Economic Research (BER) at the University of Dhaka. The survey, administered during November 2004 - February 2005, covered 1039 households in 64 districts in Bangladesh, of which about 70 percent households were located in rural areas while the rest belonged to the urban communities. The BER survey collected data on a wide variety of subjects, including household characteristics, demography, educational attainment and economic activities of household members, and consumption and expenditures on food and non-food items.

Constructing the Index of Women Empowerment: Female empowerment is measured by an index that encompasses various socio-econ-cultural aspects of the environment women reside in. It is based on 4 different indicators/indices [18]. Index for control over economic resources combines the information on whether the woman in question owns land and if she has some money at her disposal. In both instances (i.e. landholding and keeping money) we ascribe 1 for an affirmative answer and 0 for a no. Thus the index ranges from 0 to 1 (answers are equally weighted). Decision making index reflects the woman's ability to make take purchasing decisions independently. These are: (1) small purchases (food), (2) small purchases (personal items), (3) utensils, (4) apparels for children, (5) sarees (women's traditional wear), (6) apparel items for male, (7) education related expenses, (8) medical expenditures, (9) house repairing, (10) buying and selling cattle, (11) leasing land, and (12) purchasing such major items such as land, boat, rickshaw, etc. 1 is given for each 'yes' and 0 for each 'no/joint decision' and then the sum is divided by 12 . Hence the value of this index ranges from 0 to 1 . Mobility measures the woman's ability to visit certain places without consulting with their husbands or relatives. These include, (1) nearby relatives/friends, (2) haat/bazaar in the locality, (3) nearest hospital/clinic/doctor, (4) cinema/fair, (5) nearby banks/post office/public offices, (6) NGO offices/training programs, and (7) any other similar places reported by the interviewees. For each kind of place, the answer 'yes' is given a score of 1 and the 'otherwise' is awarded 0. The responses are summed and set in the 0-1 scale. And lastly Political awareness assesses a woman's political awareness. 5 questions were asked regarding the names of some political figures and the way the woman exercised her voting power. The index lies between 0 and 1 . 
The index of women empowerment: We sum all those 4 indices for each woman weighting equally to obtain the corresponding value of the empowerment index. It ranges from 0 to 4 .

To avoid the potential problems of endogeneity associated with this index and to make it more representative of the social and cultural environment in which the woman resides, we explain the index using some exogenous factors like husband's and wife's education, household's socioeconomic status (represented by HH expenditure), her participation in earning activities (offhome and in-house activities) and extended family (presence of father-in-law and mother-in-law. In a rural-based economy $\mathrm{HH}$ expenditure is prone to measurement error and also it will be affected by the $\mathrm{HH}$ characteristics that influence the empowerment. For these reasons, in the multivariate regressions, empowerment and $\mathrm{HH}$ expenditure are treated as endogenous.

\section{CONTEXT SPECIFIC DETERMINANTS OF WOMEN EMPOWERMENT}

Table 1: Women Empowerment: 2SLS regression

\begin{tabular}{|l|l|l|}
\hline \multicolumn{2}{|c|}{ Determinants of the Index of Women Empowerment } \\
\hline \multicolumn{1}{|c|}{ Variables } & Coefficients & Robust Standard Error \\
\hline Per capita HH expenditure (in logs) & -.0068877 & .1311797 \\
\hline Age & $.0451981^{* * *}$ & .0104951 \\
\hline Age squared & $-.000443^{* * *}$ & .0001261 \\
\hline Self education (class 1- class 10) & $.2880021^{* * *}$ & .0492232 \\
\hline Self education (more than class 10) & $.5688755^{* * *}$ & .1176351 \\
\hline Husband's education & -.0090992 & .0055587 \\
\hline Participation in Outside-home Earning Activities (1 if yes) & $.300855^{* * *}$ & .0451341 \\
\hline Participation in Within-home Earning Activities (1 if yes) & $.1777387^{* * *}$ & .0397025 \\
\hline If living in extended family (1 if yes) & $-.1676616^{* * *}$ & .0614054 \\
\hline Number of children > 12 years of age & -.0205337 & .0207038 \\
\hline Religion (1 if Muslim) & .0865735 & .0786245 \\
\hline Location (1 if Urban) & .0673391 & .048835 \\
\hline Constant & .1278933 & .8659142 \\
\hline Number of Observation & 990 & \\
\hline F Statistics & $17.31^{* * *}$ & \\
\hline R-squared & .1834 & \\
\hline $\boldsymbol{F}$ Statistics of Restrictions & & \\
\hline $\begin{array}{l}\text { Test Self education (class 1- class 10) } \\
\text { than class 10) Self education (more }\end{array}$ & $8.43^{* * *}$ \\
\hline $\begin{array}{l}\text { Test Participation in Outside-home Earning Activities= } \\
\text { Participation in Within-home Earning Activities }\end{array}$ & $3.92^{* *}$ \\
\hline
\end{tabular}

Note: Statistical Significance at 1, 5 and 10 percent level are denoted by ${ }^{* * *},{ }^{* *}$ and ${ }^{*}$ respectively. HH expenditure is instrumented by HH head's education, HH head's age, HH landholding and prices of rice, wheat, egg and pulse. These instruments are likely to be correlated with $\mathrm{HH}$ expenditure but uncorrelated with the error term. In the $1^{\text {st }}$ stage regression, these variables were significant with $\mathrm{R}^{2}=.3493$ and $\mathrm{F}=58.97$.

Following the regression results presented in Table 1, female empowerment increases with her age but at a decreasing rate. On average, and controlling for other factors, if the woman has 1 to 10 years of education, her empowerment index is .288 points higher compared to a woman with no education. Similarly if she has more than 10 years of education, the index is .569 points higher compared to a woman in the base category. Both these impacts are significant at less than $1 \%$ level of significance. If a woman participates in off-house earning activities, on average and other things being equal, her empowerment is significantly .301 points higher relative to a woman who doesn't participate in any kind of income generating activities. Also, compared to the benchmark woman, a woman's empowerment is positively and significantly influenced by her participation in in-house earning activities. Also if the woman resides in an extended family, her empowerment is significantly reduced. Testing of restrictions elicit that the impact of having more than 10 years of education is significantly different from the impact of having 1-10 years of education and the woman's participation in off-home earning activities raises her empowerment significantly in comparison with her participation in in-house earning activities. 


\section{IMPACTS OF EMPOWERMENT}

Table 2: Empowerment and Patterns in Female Food Consumption: 2SLS Regressions

\begin{tabular}{|l|l|l|l|}
\hline \multirow{2}{*}{ Covariates } & \multicolumn{3}{|c|}{ Dependents variables (calories) } \\
\cline { 2 - 4 } & Total & Ordinary food & Preferred food \\
\hline Per capita HH expenditure (in logs) & $.105^{*}(.054)$ & $.085(.056)$ & $1.96^{* * *}(.390)$ \\
\hline Index of empowerment & $-.149^{*}(.077)$ & $-.159^{* *}(.079)$ & $1.14^{* *}(.578)$ \\
\hline Level of activity & $.088^{*}(.047)$ & $.093^{*}(.048)$ & $.177(.268)$ \\
\hline Age & $.004(.006)$ & $.005(.006)$ & $-.077^{* *}(.039)$ \\
\hline Age squared & $-.00007(.0001)$ & $-.0001(.0001)$ & $.001^{*}(.0004)$ \\
\hline Weight-for-height & $.139^{*}(.079)$ & $.146^{*}(.081)$ & $-.788(.521)$ \\
\hline Self education & $-.001(.005)$ & $-.001(.005)$ & $.007(.034)$ \\
\hline Husband's education & $-.0001(.002)$ & $-.0004(.003)$ & $.032^{*}(.018)$ \\
\hline HH size (in logs) & $.037(.029)$ & $.035(.029)$ & $.551^{* * *}(.209)$ \\
\hline $\begin{array}{l}\text { Participation in Earning Activities }(1 \text { if } \\
\text { yes) }\end{array}$ & $.074^{* *}(.029)$ & $.075^{* *}(.029)$ & $-.237^{* *}(.222)$ \\
\hline Illness (1 if yes) & & & $-.278(.133)$ \\
\hline Pregnancy (1 if yes) & $6.93 \mathrm{e}^{-066}(.018)$ & $.0003(.018)$ & $.048(.414)$ \\
\hline Location (1 if Urban) & $-.128^{* *}(.055)$ & $-.131^{* *}(.058)$ & $-.012(.134)$ \\
\hline Constant & $-.032^{*}(.018)$ & $-.031(.019)$ & $-11.82^{* * *}(2.42)$ \\
\hline Number of Observation & $6.77^{* *}(.347)$ & $6.89^{* * *}(.354)$ & 972 \\
\hline F Statistics & 972 & 972 & $23.00^{* * *}$ \\
\hline R-squared & $3.77^{* * *}$ & $3.58^{* * *}$ & .2511 \\
\hline
\end{tabular}

Note: Statistical Significance at 1, 5 and 10 percent level are denoted by ${ }^{* * *},{ }^{* *}$ and ${ }^{*}$ respectively. Calorie variables are in logs. Endogenous: HH expenditure and the empowerment index. Inferences are based on robust standard errors (in the parentheses).

4.1 Food allocation: Food allocated to a woman is measured by her daily calorie intake. Per capita household expenditure, her level of empowerment, the level of activity performed by the woman, her weight-for-height (measure of short run health), her participation in earning activities, pregnancy status and location of the $\mathrm{HH}$ are the significant determinant of a woman's daily calorie allocation. Quite interestingly, empowerment exerts significant negative influence on her calorie consumption. But the impact on total calorie intake can be misleading as it ignores the quality of the food item. We divide the food items into two groups - preferred items (meat, egg, drinks and dairy products) and ordinary food items (mostly rice, wheat, vegetables and fish). Similar regressions reveal that more empowered women are receiving significantly lower calories from ordinary items whereas they receive significantly higher calories from preferred food items. The fact that ordinary foods are more calorie-rich can explain the negative impact of empowerment on total calorie intake. The regression results are reported in Table 5.1. Another important dimension of the influence of female empowerment on her food consumption is that empowerment significantly reduces calories received from in-house food consumption but it appreciably increases outside-home calorie consumption. Two similar regressions were run using 'in-house calorie consumption' and 'outsidehome calorie consumption' as the dependent variable. The empowerment coefficients are -.230 $(p=.014)$ and $2.13(p=.007)$ respectively. These findings may have important implications for the potential discrimination against women in food allocation.

Table 3: Empowerment and Female Expenditure: 2SLS regressions (Summary Table)

\begin{tabular}{|c|c|c|c|c|c|c|}
\hline \multicolumn{7}{|c|}{ Food Expenditure } \\
\hline \multicolumn{7}{|c|}{$-.126(.108)$} \\
\hline \multicolumn{7}{|c|}{ Non-Food Expenditure } \\
\hline \multicolumn{7}{|c|}{$.148(.247)$} \\
\hline Transports & Home related & Health & Education & Entertainment & Clothes & Personal \\
\hline $2.14^{* * * *}(.637)$ & $1.00^{* *}(.431)$ & $-.881(.690)$ & $.669^{* * *}(.271)$ & $.126(.223)$ & $.275(.353)$ & $-.662(.458)$ \\
\hline
\end{tabular}

Note: Statistical Significance at 1, 5 and 10 percent level are denoted by ${ }^{* * *},{ }^{* *}$ and ${ }^{*}$ respectively. Expenditure variables are in logs. Endogenous: HH expenditure and the empowerment index. Inferences are based on robust standard errors (in the parentheses). 
4.2 Expenditure Allocation: Similar 2SLS regressions are used to investigate the impact of empowerment on food and non-food expenditures allocated to the woman. Table 3 displays the summary findings of those regressions. Empowerment doesn't have any significant influence on the woman's food expenses. This is not surprising given the food allocation regressions. With increases in empowerment, the woman is substituting preferred food items for ordinary foods without any significant influence on her total food expenditure. Also empowerment doesn't have any significant impact on her monthly non-food expenses. However, the data set had information about non-food expenditures in various categories and using that the paper finds that more empowered women are likely to spend significantly higher amounts on expenses like - transports, home-related purchases and education.

4.3 Nutritional and Health Awareness: In the survey, 10 questions were asked about nutrition and primary health care. If all the answers were correct the woman got 1 . This index ranges between 0 and 1. Then using a 2SLS regression this index is explained by $\mathrm{HH}$ expenditure, women empowerment, education (self and spousal) and other covariates. Table 4 reports the results. A woman's empowerment is found to have a significant positive influence on her nutritional and health awareness index.

Table 4: Impacts of Women Empowerment: 2SLS regressions

\begin{tabular}{|l|l|}
\hline \multirow{2}{*}{ Covariates } & \multicolumn{1}{|c|}{ Dependents variable } \\
\cline { 2 - 2 } & Nutritional awareness \\
\hline Per capita HH expenditure (in logs) & $.082^{(.058)}$ \\
\hline Index of empowerment & $.260^{* *}(.069)$ \\
\hline Age & $-.004^{* * *}(.001)$ \\
\hline Self education & $.002(.004)$ \\
\hline Husband's education & $.008^{* * *}(.003)$ \\
\hline HH size (in logs) & $.043(.030)$ \\
\hline $\begin{array}{l}\text { Participation in Earning Activities (1 if } \\
\text { yes) }\end{array}$ & $-.092^{* * *}(.029)$ \\
\hline Location (1 if Urban) & $.046^{* *}(.020)$ \\
\hline Constant & $-.314(.377)$ \\
\hline Number of Observation & 990 \\
\hline F Statistics & $34.14^{* * *}$ \\
\hline R-squared & 0.0519 \\
\hline
\end{tabular}

Note: Statistical Significance at 1, 5 and 10 percent level are denoted by ${ }^{* * *}{ }^{* *}$ and ${ }^{*}$ respectively. Expenditure variables are in logs. Endogenous: HH expenditure and the empowerment index. Inferences are based on robust standard errors (in the parentheses).

4.4 Family Planning: The survey also inquired if the woman had taken family-planning measures. We explain this dichotomous dependent variable using $\mathrm{HH}$ expenditure, empowerment, age, education (self and spousal), HH size, participation in income generating activities and location. The IV-Probit estimation shows that female empowerment, age, husband's education and HH size are the important determinants of whether birth-control measures were adopted or not. With all other variables at their means, if the index of female empowerment equals 1 , the predicted probability that the woman took birth control measure is .5053 and the probability that she did not participate in family planning is .4947 . The probability of a 'yes' when the empowerment index is 2 is .8764 and when the index is 3 the probability of 'yes' is .9893 . Table 5 reports the probabilities and the detailed results are reported in Table 6.

Table 5: Predicted Probabilities - based on IV-Probit estimates

\begin{tabular}{|l|l|l|l|l|}
\hline \multirow{2}{*}{} & \multicolumn{2}{|l|}{ Use of birth control measure } & \multicolumn{2}{l|}{$\begin{array}{l}\text { If ordinary and preferred foods are } \\
\text { distributed differently }\end{array}$} \\
\cline { 2 - 5 } & Yes $(=1)$ & No $(=0)$ & Yes $(=1)$ & No $(=0)$ \\
\hline Empowerment index $=1$ & .5053 & .4947 & .7677 & .2323 \\
\hline Empowerment index $=2$ & .8764 & .1236 & .1032 & .8968 \\
\hline Empowerment index $=3$ & .9893 & .0107 & .0006 & .9994 \\
\hline
\end{tabular}


Table 6: Impacts of Women Empowerment: IV-Probit Estimates

\begin{tabular}{|l|l|l|}
\hline \multirow{2}{*}{ Covariates } & \multicolumn{1}{|c|}{ Dependents variables } \\
\cline { 2 - 3 } & Use Birth-control Measure & Distribute foods differently \\
\hline Per capita HH expenditure (in logs) & $.195(.239)$ & $-.364(.267)$ \\
\hline Index of empowerment & $1.144^{*}(.688)$ & $-1.995^{* *}(.781)$ \\
\hline Age & $-.058^{* * *}(.010)$ & $.026^{* *}(.011)$ \\
\hline Self education & $-.022(.038)$ & $.070(.045)$ \\
\hline Husband's education & $.039^{* * *}(.014)$ & $-.038^{* *}(.016)$ \\
\hline HH size (in logs) & $.338^{* *}(.170)$ & $.420^{* *}(.188)$ \\
\hline $\begin{array}{l}\text { Participation in Earning Activities (1 if } \\
\text { yes) }\end{array}$ & $-.043(.256)$ & $.666^{* *}(.291)$ \\
\hline Location (1 if Urban) & $-.009(.140)$ & $.429^{* * *}(.160)$ \\
\hline Constant & $-.959(1.858)$ & $3.009(2.078)$ \\
\hline Number of Observation & 1000 & 983 \\
\hline Area under the ROC curve & .6969 & .5672 \\
\hline
\end{tabular}

Note: Statistical Significance at 1, 5 and 10 percent level are denoted by ${ }^{* * * * *},{ }^{* *}$ and ${ }^{*}$ respectively. Expenditure variables are in logs. Endogenous: HH expenditure and the empowerment index. Inferences are based on robust standard errors (in the parentheses).

4.5 Discriminating Food Distribution: In typical Bangladeshi households usually women distribute (serve) the food among the family members. The survey reports that $42.70 \%$ of the women allocate ordinary and preferred foods in a dissimilar fashion among the family members. So it might be quite interesting to investigate if empowered women behave differently in this regard. We estimate an IV-Probit model; and empowerment, age, husband's education, HH size, woman's labor market participation and location are found to be exerting significant influences (results reported in the annex, Table A-2). If all other variables are at their means, when the empowerment index is 1 , the predicted probability that the woman would allocate those foods differently is .7677 . The probabilities are .1032 and .0006 when the index has values of 2 and 3 respectively. Probabilities are reported in Table 5 while Table 6 reports the determinants.

\section{CONCLUSION}

This paper has made an attempt to explore the potential determinants of the empowerment of married women in Bangladesh and then went on to investigate if female empowerment had any important bearings on other spheres of a woman's life. Using a Bangladeshi Household Survey data, an index of female empowerment is constructed taking into account of the socio-cultural background of the woman.

Some important findings of the paper are that female education, her involvement in income generating activities (both formal and informal) and the structure of the household (unit or extended) are important determinants of female empowerment. Additionally the impact of empowerment on the female's life is multifaceted. It affects her food intake and expenditure patterns. Additionally, empowerment was found to exerting significant desirable impacts on the level of a woman's nutritional and health awareness, her use of family planning measures and if the woman displays discriminatory behavior in food serving.

The findings of this paper suggests that investing in female education and creating employment opportunities for women would significantly raise their empowerment and this higher empowerment is likely to have other desirable impacts within a household.

In this paper we did not consider the potential impacts of empowerment on the food and expenditure allocations to all the members within a household. Also only married women are considered here. An interesting improvement would be to construct a more general indicator of female empowerment for all adult women using a larger sample. Also conducting controlled experiments can reveal important insights. 


\section{References}

[1] A. Stine, H. Karina, Education as a Means to Women's Empowerment, Opgave, Approaches to Development (U-landslære), Aarhus University, 2003.

[2] J. von Braun, H. de Haen, J. Blanken, Commercialization of Agriculture under Population Pressure: Effects on Production, Consumption, and Nutrition in Rwanda, Research Report No. 85. Washington D.C., International Food Policy Research Institute, 1991.

[3] S. Handa, Expenditure Behavior and Children's Welfare: An analysis of Female-headed Households in Jamaica, Journal of Development Economics 50(1), 1996, 165-187.

[4] T.P. Schultz, Testing the Neo-Classical Model of Family Labor Supply and Fertility, Journal of Human Resources, Vol. 25(4), 1990, 599-634.

[5] M. Doan, L. Bisharat, Female Autonomy and Child Nutritional Status: the Extended Family Residential Unit in Amman, Jordan, Center for the Study of Population, Florida State University, 1990.

[6] S.E. Castle, Child Fostering and Children's Nutritional Outcomes in Rural Mali: the Role of Female Status in Directing Child Transfers. Population Studies and Training Centre, Brown University, 1995.

[7] J. Hoddinott, L. Haddad, Does Female Income Share Influence Household Expenditures? Evidence from the Côte d'Ivoire. Oxford Bulletin of Economics and Statistics 57 (1), 1995, 77-96.

[8] P.L. Engle, Maternal Work and Child Care Strategies in Peri-urban Guatemala: Nutritional Effects. Child Development 62, 1991, 954-965.

[9] A.R. Quisumbing, J.A. Maluccio, Resources at Marriage and Intra-Household Allocation: Evidence from Bangladesh, Ethiopia, Indonesia and South Africa, Oxford Bulletin of Economics and Statistics, 65, 3 (2003).

[10] P. Kantor, Women's Empowerment Through Home-based Work: Evidence from India. Development and Change 34 (3), 2003, 425-445.

[11] S.J. Jejeebhoy, Z.A. Sathar, Women's Autonomy in India and Pakistan: The Influence of Religion and Region, Population and Development Review 27 (4), 2001, 687-712.

[12] S. Jayaweera, Women Education and Empowerment in Asia, Gender and Education, Volume 9, Number 4 / December 1, 1997, 411 - 424.

[13] A. Malhotra, S.R. Schuler, C. Boender, Measuring Women's Empowerment as a Variable in International Development, Background Paper Prepared for the World Bank Workshop on Poverty and Gender: New Perspectives, 2002.

[14] S.M. Hashemi, S.R. Schuler, Defining and Studying Empowerment of Women: A Research Note From Bangladesh, in JSI Working Paper No.3, Arlington, Virginia 1993.

[15] N. Kabeer, Resources, Agency, Achievements : Reflections on the Measurement of Women's Empowerment, Development and Change 30, 1999, 435-464.

[16] S. Anderson, M. Eswaran, What Determines Female Autonomy? Evidence from Bangladesh. Department of Economics, University of British Columbia, 2005.

[17] C.E. Levin, D.G. Maxwell, M. Armar-Klemesu, M.T. Ruel, S.S. Morris, C. Ahiadeke, Working Women in an Urban Setting: Traders, Vendors, and Food Security in Accra, FCND Discussion Paper no. 66, 1999.

[18] M. M. K. Toufique, M. A. Razzaque, Domestic Violence Against Women: Its Determinants and Implications for Gender Resource Allocation, Research Paper No. 2007/80, UNU-WIDER, 2007. 